\title{
ESTRi
}

Environmental Studies and Policy

Research Institute|Wroclaw

\section{The River that Divided a Nation: \\ Rhetoric, Environmental Activism and the Political Controversy over the Rospuda River Valley in Poland}

Julia Ziemińska and Kacper Szulecki

ESPRi Working Paper No. 1 - February 2010 


\begin{abstract}
Are environmental norms uniform in the EU and if yes - how does that happen? This article demonstrates the process through which norms are transnationally enforced in Europe. It also engages in a theoretical discussion with constructivist research on normative change, arguing for the need to take domestic agency, as well as local ideational structures, into account while also questioning the usefulness of the concept of "socialization" and the notion of "norm diffusion" in the debate on Europeanization. Instead, normative change could be perceived as the empowerment of certain norms and values at the cost of others. A four stage model of norm empowerment is developed, utilizing the mechanism of rhetorical coercion, and tested on the case of a recent environmental controversy over the preservation of the Rospuda river valley in Poland. It is argued that normative change on the level of domestic discourses can be observed and analyzed parallel to the rhetorical practices of societal actors. Mobilization and contestation thus resembles electoral campaigns, and framing, rhetorical coercion as well as entrapment are the most important mechanisms in play, while the EU can be seen as a stabilizer of the normative "status quo" which is the result of the conflict.
\end{abstract}

\title{
Citation
}

Ziemińska, Julia and Kacper Szulecki. 2010. The River that Divided a Nation: Rhetoric, Environmental Activism and the Political Controversy over the Rospuda River Valley in Poland. ESPRi Working Paper No 1. February 2010.

Available at www.espri.org.pl.

(C) 2010 - All rights remain with the authors.

Contact:

Kacper Szulecki, University of Constance and ESPRi

E-mail: kacper.szulecki@uni-konstanz.de

Julia Ziemińska, Lake Constance Foundation and ESPRi

E-mail: julia.zieminska@gmail.com 


\section{Acknowledgement}

We would like to thank Jeff Checkel, Patrick T. Jackson, Dirk Leuffen, Liudmila Mikalayeva, Philipp Pattberg and Frank Schimmelfennig, as well as the participants of the research seminar "European Integration and Governance" at the Centre for Comparative and International Studies (CECIS), ETH/University of Zurich for their comments and words of encouragement.

\section{Content}

1. Introduction

2. The Puzzle and Possible Explanations

3. Changing Norms and Practices: A Review of Literature

4. Theory and Methodology: Tracing Norm Empowerment on Two Levels

Discursive Structures

Agency: A Model of Norm Empowerment

5. Green Empowerment: A Process Tracing Analysis of the Rospuda Conflict

Phase I: Norm Hegemony - The Conflict Breaks Out

Phase II: Framing Struggle - The Conflict Escalates

Phase III: Relative Superiority - From "Cheap Talk" to "Entrapment" 


\section{Introduction}

In a recent controversy in Poland, which started out as a conflict between local government and environmental activists, vast societal masses were mobilized and took sides in an argument that erupted over a river valley cutting across the suburbs of an impoverished town. The community of Augustów in north-western Poland would strongly benefit from the long overdue improvements in infrastructure. Among them, the town's bypass which would be part of a larger project, the Via Baltica motorway, connecting Berlin, Warsaw and Vilnius, is the most important infrastructural goal. However, the motorway was planned to cross the wetlands and marshes surrounding the small Rospuda river, declared an "environmental treasure" by numerous Polish and Western European specialists. ${ }^{1}$ The battle over this tiny piece of land gained enormous regional, and (inter)national attention. It mobilized all possible stakeholder groups at different levels (local, regional, state, EU) and from different sectors (public authorities, NGOs, epistemic communities, the media, road construction companies, the European Commission). The result of this political controversy was not only a new project for the motorway - detouring the river valley, but also a surprising example of the role social movements can play in mobilizing various actors as well as framing issues at stake, and what is more - the way environmental concerns can be made to dominate over modernizing tendencies because of EU pressure.

The question is then why was the more pro-environmental option chosen in the end? Can this be due to a normative change that occurred in Poland and can it have longterm effects? Or to state it in more general terms: why and how are environmental protection practices (not legislation) and norms uniform in the EU? This article shows the process through which norms are transnationally enforced in Europe. It also engages in a theoretical discussion with existing social constructivist approaches to normative change, arguing for the need to take domestic agency as well as local "ideational landscapes" more seriously, while also questioning the usefulness of the concept of "socialization" and the notion of "norm diffusion" in the literature on Europeanization. Instead, we propose to look at normative change as the empowerment of certain norms and values at the cost of others.

\section{The Puzzle and Possible Explanations}

Why did the Polish authorities decide to pursue a different project and leave the Rospuda River valley in its present state? Several possible explanations instantly come to mind. It could be assumed that the elections that took place in Poland while the controversy was at its peak can be the most important explanatory factor (interestingly, one that is also very often ignored by scholars analyzing normative change and "socialization"). And yet Civic Platform (Platforma Obywatelska - PO), the party that replaced Law and Justice (Prawo i Sprawiedliwość - PiS) and formed the new government, can hardly be referred to as "green". A conservative government was replaced by a liberal-

\footnotetext{
${ }^{1}$ Kozak, Marcin (2007), 'Save Rospuda Valley', Current Science, 93(1): 6.
} 
conservative one. ${ }^{2}$ The programme of the new authorities emphasized the need to build infrastructure and prioritize "cheap" development. The "environmentally sound" option in the Rospuda controversy was not necessarily the cheaper one. And yet, something had to change in the general political discourse in Poland if a liberal party of this kind finally sided with environmentalists and ignored those (important) societal voices that called for the construction of the highway "here and now".

Again, there are at least three possible explanations of that outcome. One can be called "legalistic" and argues that if the motorway was in the end declared "illegal" by the European Court of Justice and Polish courts, it was illegal from the start and thus it was only a matter of time before the controversy would end as it did. In fact, law is rather "what we make of it", and subject to context-dependent interpretation. One needs to bear in mind that those same Polish courts that withdrew the construction permit for Via Baltica had issued it in the first place. The illegal "nature" of the motorway depended to a great extent on the interpretation of "what the Rospuda really means" - is it "just a river" or a "treasure of international importance", and so it depended on the values and norms present in the debate. Thus law becomes a discursive practice as any other. Moreover, a different scenario, one in which the authorities would push for the construction of the motorway so that it becomes fait accompli (the tactics used by the PiS government as we shall see) was also possible, brushing legal considerations aside.

Another explanation points to the material conditionality of the EU, and suggests that the government's decision was strategic and was only a way to deflect negative consequences and pressures from "Europe". EU pressures are undeniable, but if that hypothesis was to be true, the government should be resolving other similar controversies between development and the environment, ones less publicized and not in the EUspotlight, in favour of economic growth and developmental concerns. That is not the case. Since the elections, there were several similar situations, though on a smaller scale, all of which were resolved not only in an environmentally sound way, but also (mostly) according to different, more participatory governance procedures. Also, a decision to build the motorway as planned was not bound to bring material penalties on the Polish government (through EC sanctions). The choice between development and the environment necessarily includes a trade-off. If a liberal party consistently chooses to act against its ideology, we may hypothesize that some external "circumstances" or "factors" constrain its action. These are, we argue, ideational and rhetorical.

The third possible explanation, this time more "social" than "material", one that would be offered by constructivist scholars of "norm diffusion", suggest that "socialization" to some common norms has occurred. We do agree that a certain uniformization of norms within the EU is observable, thus allowing for the notion of "Europeanization" to be used. However, a closer look at the domestic level proceedings questions the idea of "socialization" or "diffusion" (suggesting the "movement" of norms from the outside-in, and into contexts where they were previously absent). There is not enough space in this article to provide a full exposition of evidence (in the form of a "genealogy" of environmental norms in Europe and Poland). At this point it should suffice to say that norms of environmental protection were not introduced in Poland through EU pressure, but

\footnotetext{
${ }^{2}$ A political commentary written well before the elections, when the Rospuda controversy was only beginning, noticed the problem the opposition (then PO and the social democrats) can have with taking a stance. While the left was a natural "friend" of the environmentalists, PO was expected to opt for highways and modernization or to avoid the issue. See: Medeksza, Łukasz (2007), 'Co lepsze: rozwój czy przyroda? Rząd stawia na rozwój', Pardon, 15.02. 2007. Available online at: http://www.pardon.pl/artykul/903 Lco lepsze rozwoj_czy przyroda rzad stawia na rozwoj (2.09.2009).
} 
rather existed in the "ideational landscape" for decades. It can be assumed that it is not then so much the introduction of new norms, but rather the empowerment of certain values and the weakening of others.

In this article we seek to analyze the process of normative change trough the perspective of "norm empowerment". We first position my argument briefly within the social constructivist debate on "normative change" and the role of social movements as well as the so called "transnational advocacy networks". Having done that, we introduce my approach to this question, and propose a model of "norm empowerment" in the EU, which traces the process of normative change in time and on two levels - the structural level of discourse and the level of societal actor's agency. We then use the methods of process tracing and discourse analysis to operationalize the model and make it empirically applicable. This is followed by the main empirical part showing the way norm empowerment in Poland occurred.

\section{Changing Norms and Practices: A Review of Literature}

Normative change has been at the heart of the constructivist research agenda for many years. ${ }^{3}$ The same goes for social movements the theory of which helped bridge constructivist IR scholarship and older sociological analyses. ${ }^{4}$ The transnational dimension of activism, as well as the need to investigate domestic political processes became apparent. ${ }^{5}$ Keck and Sikkink's ${ }^{6}$ milestone work in this strand introduces the concept of transnational advocacy networks (TANs). These are supposed to appear under the scope conditions specified by the "boomerang model"7 of transnational mobilization - in cases where domestically operating societal actors are not by themselves able to influence their governments, but their agenda is translatable for a transnational network. The most important action that TANs undertake is the framing of issues in such a way as to appeal to societies and powerful actors, and convince these to take action. "Framing" is a concept borrowed from sociology and social movements' theory. ${ }^{9}$ However, in its mainstream IR constructivist version, it is very often a strategic action rather than a discursively constituted practice. While clearly a groundbreaking work, Keck and Sikkink's book has little to say about the causal mechanisms involved in the operations of TANs and the campaigns they undertake. It also shows some traces symptomatic for the conventional constructivist school, namely, it overemphasizes the international and transnational at the cost of the domestic level politics. Additionally, it fails to incorporate cultural phenomena and the ways certain frames are created by linking pre-existing symbolic elements, but also how meaning is constructed and reproduced. Because of that,

\footnotetext{
3 Finnemore, Martha and Kathryn Sikkink (1998), 'International Norm Dynamics and Political Change', International Organization, 52(4): 887-917.

${ }^{4}$ Finnemore, Martha (1996), 'Norms, Culture, and World Politics: Insights from Sociology's Institutionalism', International Organization, 50 (2): 325-347.

5 Risse-Kappen, Thomas (ed.) (1995) Bringing transnational relations back in - Non-state actors, domestic structures and international institutions. Cambridge: CUP; Risse, Thomas (1999) 'International Norms and Domestic Change: Arguing and Communicative Behavior in the Human Rights Area' Politics and Society 27: $529-559$.

${ }^{6}$ Keck Margaret and Kathryn Sikkink (1998), Activists beyond Borders, Ithaca and London: Cornell University Press.

7 Ibidem: 13

8 Ibidem: 17

${ }_{9}^{9}$ cf. Goffman, Ervin (1986), Frame Analysis: An Essay on the Organization of Experience, York: Notheastern.
} 
the notion of "symbolic politics" performed by TANs is rather thin, ${ }^{10}$ and refers only to using "symbolic events" to support a cause. We propose to expand this notion and look at the "politics of meaning" that activists perform.

The book by Risse, Ropp and Sikkink ${ }^{11}$ is meant to expand the findings of Keck and Sikkink by presenting "a causal argument about the effects of transnational advocacy networks in processes of norm diffusion".12 The authors propose a five-phase "spiral model" of normative change, which is specifically related to human rights issues and the "socialization" of "pariah states". What Risse et al. insist on is the idea of "socialization" as a process through which states are made to conform to "international" norms. ${ }^{13}$ This process takes place in stages, and the mechanisms in play are instrumental adaptation, later followed by "deeper" ones - argumentation, dialogue and persuasion (this is where the work is heavily indebted to Habermas).

The notion of "socialization" suggests that norms that previously did not exist are imposed on a certain group of actors. As we try to show it is not always the case, neither with human rights norms and ideas, nor with environmental values. ${ }^{14}$ That is why for investigating instances of normative change we propose to think of it in terms of norm "empowerment".

Communicative rationality and the notions of "persuasion", "argumentation" and "dialogue" on the other hand imply some objective moral superiority of certain norms. We are not attempting to sneak in some form of moral relativism, but in many cases where scholars speak of persuasion (e.g. in the context of intergovernmental negotiations), arguments are not on an ethical level (at least not always). The insistence on persuasion also takes the ideal typical assumptions of Habermasian communicative action into the empirical world. We propose to look at political communication through the lens of classical rhetoric - understood as the art of persuading the audience not to the better argument but to one's own argument (the moral implications of this understanding of rhetoric are famously discussed in Plato's dialogue "Gorgias"). ${ }^{15}$

A similar idea is proposed by Krebs and Jackson. ${ }^{16}$ These authors argue for the reintroduction of rhetoric into the analysis of political contestation. They propose a model of "rhetorical coercion", which makes an analytical division between "frames" and "implications". In a public debate, it is possible to rhetorically "coerce" the opponent in such a way that she either agrees on the general understanding of the issue (the frame) or also its policy implications. The arguing parties are constrained by the rhetorical material provided by the discourse they share. The elements of this discourse, which they can call up and to which they can refer to support their arguments are known as "commonplaces". ${ }^{17}$ We draw on Krebs and Jackson in that we substitute persuasion for rhetorical coercion as the single most important causal mechanism in the process of political de-

\footnotetext{
${ }^{10}$ Keck, Margaret and Kathryn Sikkink, op. cit.: 22

${ }^{11}$ Risse, Thomas, Stephen Ropp and Kathryn Sikkink (eds.) (1999), The Power of Human Rights: International Norms and Domestic Change, Cambridge: Cambridge University Press.

12 Risse, Thomas and Kathryn Sikkink (1999), 'The Socialization of International Human Rights Norms into Domestic Practices: Introduction', in: Risse, Thomas, Stephen Ropp and Kathryn Sikkink, op. cit.: 1-38.

13 Ibidem: 5 .

${ }^{14}$ cf. Szulecki, Kacper (forthcoming 2010) 'Smashing concrete with words: the Central European "dissidents", their discourses and representations', in: Fischer, Sabine and Heiko Pleines (eds), Civil Society in Central and Eastern Europe, Stuttgart: Ibidem Publishers.

15 Plato, (1994), Gorgias, NY: Oxford University Press.

${ }^{16}$ Krebs, Ronald R. and Patrick Thaddeus Jackson, (2007), 'Twisting tongues and Twisting Arms: The Power of Political Rhetoric', European Journal of International Relations, 13(1): 35-66.

17 This is a variation of the classical rhetorical notion of loci communes or topoi, and which in my theoretical discussion is the element of the "ideational landscape".
} 
bate. However, we suggest a wider four-stage model of norm empowerment in which we disaggregate the debate into different phases, identify the key actors in each, and show the way two competing values and norms are actually struggling for domination in the public sphere. This goes beyond Krebs and Jackson's typological model, turning the mechanism of rhetorical coercion into a driving force of the process of norm empowerment. We also hypothesize about the conditions needed for the outcome of the debate to remain stable (having dismissed the possibility to judge about actual "internalization" or "socialization" of norms).

\section{Theory and Methodology: Tracing Norm Empowerment on Two Levels}

The model of norm empowerment proposed here allows for the inclusion of some important factors omitted elsewhere in the literature. Firstly, it does not take the domestic level as a tabula rasa only waiting to be filled with some normative content of "external" origin. While such notions as framing, grafting and norm resonance are already present in the literature on norms proliferation, ${ }^{18}$ we suggest that they be at the centre of analysis. And so should the domestic "ideational landscape" which is composed of discourses and values and constitutes the rhetorical reservoir for the actors to draw upon. Lastly, socialization implies a "change in the heads" of some ill-defined individuals. Through norm empowerment we can understand normative change as a shift in legitimacy, and thus explain why certain actions taken or statements uttered previously become almost unthinkable, or at least hardly acceptable, after the change has occurred.

It should already become apparent that this analysis takes into account both structural and agency-related factors. While such elements as local discourses and traditions, forming the ideational landscape of the domestic, as well as the content of values and norms are structures (constituting the field of possible agency), actions such as framing or grafting are to a considerable extent conscious and strategic (leading to the empowerment of certain behaviors and de-legitimization of others). That is why this analysis adheres to a social constructivist ontology, seeing agents and structures as mutually constitutive. We would argue, however, that actors are far more constrained by the discursive material that they "work with" than many constructivist scholars would suggest. ${ }^{19}$ Environmental activists in the case of Rospuda are not "norm entrepreneurs" - they do not "invent" any norms or values, they only call up ones that are already established, but for various reasons are in a less privileged position than other ones. Normative change is thus much more about changing the emphasis on particular values than about bringing in completely new ones.

Bearing in mind the aforementioned problem of agency and structure, for the sake of theoretical clarity we keep the analysis on two levels, which we investigate in time-periods. This idea is close to what is known in social scientific methodology as "temporal sequencing". ${ }^{20}$ However, this "technique" presupposes two completely differ-

18 Finnemore, Martha and Kathryn Sikkink (2001). Taking stock: The constructivist research in international relations and comparative politics. Annual Review of Political Science, 4, 391-416; Price, Richard (1997) The Chemical Weapons Taboo, Ithaca: Cornell University Press.

19 e.g. Price, Richard (1998) 'Reversing the Gun Sights: Transnational Civil Society Targets Land Mines', International Organization, 52(3): 613-644; compare: Krebs, Ronald R. and Patrick T. Jackson, op. cit.: 45 ${ }^{20}$ Caporaso, James A., Jeffrey T. Checkel and Joseph Jupille (2003) 'Integrating Institutions. Theory, Method and the Study of the European Union - Introduction', Comparative Political Studies, 36 (1/2): 7-40. 
ent theoretical approaches which are applied to the analysis of one case at different points in time, thus creating many cases within. ${ }^{21}$ The logic of my proposed model of norm empowerment through social mobilization in Europe is somewhat different. We try to keep the levels of analysis (structural and agent-centered) separate, but by adding the temporal dimension, we seek to observe change and put forth some (modest) claims regarding the relation between the two levels. The empirical analysis provided later employs the method of process tracing, ${ }^{22}$ in which the model proposed and the mechanisms that it theorizes are "traced" - that is visible implications of the mechanisms are provided as evidence. ${ }^{23}$

\section{Discursive Structures}

On the "structural" level, we try to show how Polish public discourse related to developmental and environmental concerns changed overtime. We propose a four-partite continuum of values associated with nature and corresponding norms (Figure 1) ${ }^{24}$ based on the historical and philosophical literature on the "genealogy" of Western environmental ideas. ${ }^{25}$

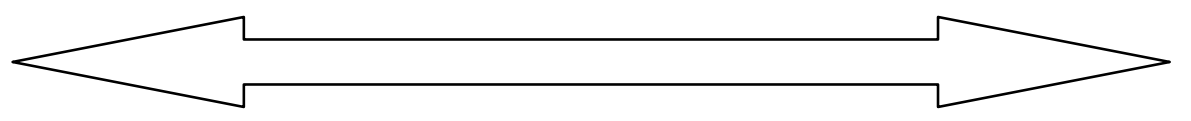

\begin{tabular}{|c|c|c|c|c|c|}
\hline Development & 1 & 2 & 3 & 4 & Environment \\
\hline Value & $\begin{array}{l}\text { Nature is a } \\
\text { resource for } \\
\text { development }\end{array}$ & $\begin{array}{l}\text { Nature is valu- } \\
\text { able, a rare re- } \\
\text { source }\end{array}$ & $\begin{array}{l}\text { Nature is a common } \\
\text { good }\end{array}$ & $\begin{array}{l}\text { Nature has } \\
\text { intrinsic value }\end{array}$ & Value \\
\hline Norm & $\begin{array}{l}\text { No protection, } \\
\text { modernization } \\
\text { is the goal }\end{array}$ & $\begin{array}{l}\text { Basic protection, } \\
\text { usually by private } \\
\text { means, develop- } \\
\text { ment comes first }\end{array}$ & $\begin{array}{l}\text { Public protection, } \\
\text { conservation, com- } \\
\text { pensation of envi- } \\
\text { ronmental losses }\end{array}$ & $\begin{array}{l}\text { It is to be } \\
\text { protected at } \\
\text { any cost, de- } \\
\text { velopment } \\
\text { has to be put } \\
\text { aside }\end{array}$ & Norm \\
\hline
\end{tabular}

Figure 1 - Development/Environment Values and Norms ${ }^{26}$

\footnotetext{
21 cf. Risse, Thomas, Stephen Ropp and Kathryn Sikkink (eds.) op. cit.

22 Checkel, Jeffrey T., (2008) 'Process Tracing,' in: Klotz, Audie and Deepa Prakash (eds.), Qualitative Methods in International Relations: A Pluralist Guide, NY: Palgrave Macmillan; Bennett, Andrew, (2008), 'Process Tracing: A Bayesian Approach,' in: Box-Steffensmeier, Janet, Henry Brady and David Collier (eds.), Oxford Handbook of Political Methodology, Oxford: Oxford University Press.

23 This may seem to be a purely deductive exercise - it is not. No theorization happens without any awareness of the empirical world. The model proposed here was developed after the data gathering on the Rospuda controversy and the preliminary analysis of the findings have shown that alternative theories and existing models cannot explain the outcome.

${ }^{24}$ Values could also be formulated from the perspective of development, however, in this analysis it is more important to focus on the environmental side.

25 The discussion of the development of environmental norms in the West, Europe can be found in: Merchant, Carolyn (2003) Reinventing Eden. The Fate of Nature in Western Culture. New York: Routledge; Boyle, Alan and Michael Anderson (1998) Human Rights Approaches to Environmental Protection, Oxford: Oxford University Press; Nedrelid, Tove (1991) 'Use of Nature as a Norwegian Characteristic', Ethnologia Scandinavica, 21: 19-33. An introduction to how these values translate to actual legislation are discussed in: Usui, Yoichiro (2003) 'Evolving Environmental Norms in the European Union', European Law Journal, 9(1): 69-87. Hellmund, Paul and Daniel Smith (2006) Designing Greenways. Sustainable Landscapes for Nature and People, Washington: Island Press. See also: Rousseau, Jean-Jacques (1987) The Basic Political Writings. Hackett Publishing Company: Indianapolis.

26 Risse and Sikkink link norms to ideas, as the individual "cognitive commitments". We chose to look at values as social rather than individual, and thus graspable in discourse analysis. Risse, T. and K. Sikkink, op. cit:: 7.
} 
Each of the four values represents a different balance struck between the two mutually exclusive extremes of "Development" and "Environment". The first possible standpoint sees nature as a mere resource for development. Accordingly, the associated norm is that of "non-protection", as the ultimate goal is "modernization". The second standpoint still treats nature as a resource, but acknowledges its value, and thus prescribes basic (often private) protection of some "most valuable" elements. The third standpoint perceives nature as a common good, yet it is still anthropocentric. It calls for public protection of the environment, as well as the compensation of environmental losses. The last and most radically environmentalist standpoint does not perceive development as a goal, and argues that nature has intrinsic value that does not have to be measured in any economic or in fact any "human" way. Nature thus has to be protected and always prioritized.

Norms are conceptualized as behavioral prescriptions linked to respective values. And thus it is possible to hypothesize about the values held by individuals and groups on the basis of their actions and statements, in which norms are called up. This approach assumes that human behavior is not only instrumentally rational, but more often is driven by a form of bounded rationality, also described as logic of appropriateness in the literature. ${ }^{27}$ Interests are constituted by identities and norms to which individuals and groups adhere. ${ }^{28}$ While norms guide the behavior or "practices" of human beings as actors, they are not 'visible' in their actions other than communication. This means that the only way to know of one's norms is through an analysis of the speech acts and texts that she or he produces.

That is why we chose a discourse analytic approach for the purpose of this study. We believe, however, that based on this approach it is very difficult to theorize about the identities of actors. A norm can be linked to more than one identity. For example, an individual can justify her behavior by calling up various identities. $X$ can say that she "is European" or "a left-winger" and therefore "willing to protect the environment", but she can also claim that she "is Christian" and wants to protect "nature as God's creation". Roots being different, the result remains the same. Because identities and norms do not come in "fixed packages", there is much place for strategic (or at least conscious) agency in creating representations and framing issues in such ways so as to make them resonate with many "traditions" and identities.

Normative change is understood not in the deeper sense of norm internalization, but rather as the change in the "ideational landscape", in which values and norms are present and which they can dominate. To investigate normative change, we probe the public discourse in Poland for the expression of certain norms, and then observe their relations in time. This exercise is based on the assumption, that the media, and especially the press, can be treated as a sphere of public debate, in which ideas, values and discourses are called up, challenged and reformed. Press articles are in some sense "merely" the expression of the opinions their authors have. However, by the fact of being voiced, these texts add to the general public discourse. On the other hand, authors, as all those enmeshed in a certain public discourse, are not taking their ideas ex nihilo. Previous texts, existing traditions and established ideas constrain possible standpoints, but also constitute the range of choices. If one is careful and separates individual agency

\footnotetext{
${ }^{27}$ Fearon, James and Alexander Wendt (2002) 'Rationalism v. Constructivism: A Skeptical View'. In: W. Carlsnaes, Thomas Risse and Beth Simmons (eds.) Handbook of International Relations. London: Sage Publications: 52- 72.

${ }^{28}$ Checkel, Jeffrey T. (1998) 'The Constructivist Turn in International Relations Theory', World Politics, 50(2): 324-348.
} 
from the constitutive structural background, a discourse analytic approach to various media outlets can justifiably be treated as an analysis of the public discourse.

To organize the interpretive analysis of texts we use the method of semantic field analysis and its particular genre, the tool of multi-aspect definitions ${ }^{29}$ borrowed from the field of media studies. To grasp the full meaning of a term analyzed it is necessary, according to Robin, ${ }^{30}$ to seemingly divide and apportion the sequence of an enunciation and re-compose it again with meaningful readability. In other words, to depict the semantic field of a term we have to study its connotations, contexts, its distributions and linkages. The netting of the semantic field starts with looking for words and phrases, which perform certain functions against the studied object. ${ }^{31}$ Having established the semantic network by accumulating the characteristics of the object, we can proceed to grasp its meanings. When the corpus of texts, creating the semantic field, is broad (as in the case of Rospuda), we can reconstruct a set of hidden definitions of the object. When the net is diverse we may have to create more than one definition.

According to my conceptualization, definitions can serve as indicators of norms to which a certain group adheres. Definitions contain utterances of both attitudes towards the object (Rospuda) and expressions of actions that need to be taken. The expression of attitude can be treated as an indicator of values - i.e. "Rospuda is a natural treasure" suggests the belief that nature have intrinsic value, and it is matched with "which needs to be protected at all costs" - an indicator of the norm or environmental preservation. An inductive reading of the wide sample of media texts resulted in distinguishing twelve definitions of "what the Rospuda is". ${ }^{32}$ To perform the analysis, We chose only those that can logically be linked to the four values and norms mentioned (Table 1).

\begin{tabular}{|c|l|l|l|l|}
\hline NORM & 1. No Protection & 2. Basic Protection & $\begin{array}{l}\text { 3. Conservation/ } \\
\text { Compensation }\end{array}$ & $\begin{array}{l}\text { 4. Environmental } \\
\text { Preservation }\end{array}$ \\
\hline DEFINITIONS & $\begin{array}{l}\text { "Negative Chris- } \\
\text { tian" definition - } \\
\text { the typically con- } \\
\text { servative one }\end{array}$ & $\begin{array}{l}\text { "Eco-terrorism" } \\
\text { and "Radical Local" } \\
\text { definitions of } \\
\text { Rospuda }\end{array}$ & $\begin{array}{l}\text { "Rational/Liberal" } \\
\text { definition }\end{array}$ & $\begin{array}{l}\text { "Green moderniza- } \\
\text { tion", "Green Radical" } \\
\text { and "Positive Chris- } \\
\text { tian" }\end{array}$ \\
\hline
\end{tabular}

Table 1 - Four norms and corresponding definitions

In order to describe the normative structure of the Polish society and to look for changes in it, a diachronic qualitative analysis (using the aforementioned method) of a sample of media was performed, and the results where then quantified to illustrate the change in

\footnotetext{
${ }^{29}$ Kłosiński, Michał (1994) 'Semantyczna Analiza Pojęć „Bezrobocie” i „Bezrobotny” w Wypowiedziach Prasowych', Kultura i Społeczeństwo 3.

${ }^{30}$ Robin, Regine (1973) Histoire et Linguistique. Paris: Colin.

31 These functions are attributes (what is the nature of the subject, how are its characteristics, etc), associations (to what is the subject related, linked), oppositions (what are its oppositions, antitheses), equivalents (how is it identified, what could replace it in a given context), object's actions (its activities and their effects) and acts towards the object (which activities are taken toward it).

32 The reading technique involved was quite demanding. First, all 546 articles were read, and all possible multi-aspect definitions were created. These were then clustered according to the previously presented conceptualization of values, in a deductive and theoretically informed manner. Definitions are thus signals of values and norms. It is possible to see them rather as visible indicators of certain discourses, in a discourse theoretic sense. Such a conceptualization, however, would make it difficult to engage in dialogue with more mainstream social constructivist writings on norms. The full twelve definitions, as well as the detailed description of coding and the full coding tables are available with the authors.
} 
time. The sample analyzed contains 546 articles published in local, regional as well as national media.

\section{Agency: A Model of Norm Empowerment}

While on the structural level it is possible to observe change, even if it is problematic to argue about the "causes" that brought it about, the level of agency can be investigated in more detail. We propose a model of norm empowerment consisting of four stages. At each stage different actors play key roles and different actions as well as mechanisms matter. What we call normative change is conceptualized as norm empowerment, that is certain norms become (re)affirmed in the domestic context, while others are marginalized. This outcome, however, is not set in stone, and can itself be subject to contestation if a different controversy arises. The stability of certain norms and the instability of others is "guaranteed", we argue, by the transnational context of the EU.

The initial phase can be described as Norm Hegemony, characterized by the unquestioned domination of one value-norm tandem over others. This should be reflected in the public discourse, where the norm has a strong position. From this initial stage the process takes off, driven by the advocates of a competing norm. The key advocacy groups can already be identified, and the initial attempts to destabilize the dominant position of one norm are undertaken. These are countered by active denial of the legitimacy of these claims, based on the dominant value-norm. Once the struggle becomes visible in the domestic media, and thus enters the space of public debate and it is impossible for those in power to ignore it, the process reaches the second phase.

This stage, to which we refer as the Framing Struggle, is a discursive battle over the "turf" in public debate, the definition of the issue, the "taking over" of important traditions and notions with which the values argued can be reinforced and mobilizing wider social "masses" as well as important political and cultural figures. It is also the moment when the advocates of either norm can be heard beyond borders, if only they succeed in framing their issue in a way that it becomes understandable and worthwhile for a wider, transnational audience. The key concepts at this stage are then framing, grafting and mobilization. The frames that compete in the dispute are developed at this stage, and the actors make attempts to graft them into the "ideational landscape", performing not only what Keck and Sikkink call "symbolic politics", but also "politics of meaning". ${ }^{33}$ At this point, rhetorical coercion becomes visible, ${ }^{34}$ but actors concentrate on attempts to be heard and to mobilize vast support (but not yet to convince those who are against the ideas they advocate). The media outlets can be expected to be "jammed" with both sides arguing their cases.

Once one side starts to clearly dominate in the conflict and its mobilizing efforts bear fruit, we can observe the transition to a next stage, namely Relative Superiority of one of the advocated values. Here, the mechanism of rhetorical coercion enters into play. As previously suggested, it is not the better argument that wins, but the one which in a specific discursive context is more convincing. At this stage one frame of the issue becomes dominant, and gradually marginalizes the other one, while the contest moves from the frame (already accepted) to the argument over its policy implications (implication contest). This is done with the help of the media, as well as external and domestic pressures. Key figures at this stage can become "entrapped" in the discourse of the dominant side, even if they were not willing to support it initially. However, because one

\footnotetext{
33 Keck, M. and K. Sikkink, op. cit.: 22-23.

34 This phase represents the situation of a framing contest in Krebs and Jackson's model of rhetorical coercion. Both sides of the conflict compete over the definition - or frame - of the issue.
} 
side starts to make claims of political legitimacy, the "mobilization of shame", 35 also transnational, can become more evident. The side losing the "discursive battle" can resort to non-discursive measures in desperate attempts to reverse the situation.

The longer this relative superiority of one norm lasts, and the more stable and firm the context becomes (here again the stability provided by external actors if they side with one of the groups). In the end, the value reaches a Stable Position, and either the challenging value is again marginalized, or the previously hegemonic one becomes the challenger. If the latter happens, we should expect policy change, as both the frame and its implications should by now be agreed upon. Domination of one value is secure, which is expressed in the public discourse, and the behavior of actors is consistent with the dominant norm even in cases which are farther from the issue that initially ignited the conflict.

We hypothesize that because norms and values are not fully, but only temporarily stable in a given discursive context, there is a need for some additional factor to enforce stability. We believe within the context of Europe, the European Union plays this role. We would thus expect to see both material and rhetorical action from the side of the EU as measures taken to create a situation of political stability in which the norms preferred by the EU dominate. The EU is a unique political community in the sense that it is closest to an ideal of an "international society" (even if only with a limited membership, but then - so are national societies), with common institutions and also, we argue, the urge to uniformization of values and norms. That is why this article adds to the debate on Europeanization, especially as it relates to norms and the "New Europe" or the EU's near neighborhood.

\section{Green Empowerment: A Process Tracing Analysis of the Rospuda Conflict}

\section{Phase I: Norm Hegemony - The Conflict Breaks Out}

"The Tatra Mountains should be for the Poles, not for marmots" Antoni Tokarczuk, then Minister of the Environment, famously declared in 2001, pointing to the apparent need to open Poland's major national park for mass tourism and investment - and firing the director of the Park who was not willing to sacrifice its integrity. ${ }^{36}$ This statement is a good illustration of the perspective on environmental issues that dominated the Polish political discourse at the turn of the century. Nature - yes, but mostly as a decoration. Environmentalism was considered a radical nuisance and a Western fad. 37 "Environmental protection is replaced by the cult of the environment and becomes an aim in itself. Instead of serving a common purpose, protected areas are less and less available to the general public" noted a Catholic ethics professor in the top opinion daily "Rzeczpospolita". ${ }^{38}$ At the outset of the Rospuda "campaign", 33\% of the analyzed media articles expressed the view of nature as a resource requiring basic protection, and an additional $30 \%$ supported public protection and conservation with an emphasis on modernization. ${ }^{39}$ The calls for taking nature into account were most often dismissed with the

\footnotetext{
${ }^{35}$ Keck, M. and K. Sikkink, op. cit.: 23; cf. Krebs, R. and P. T. Jackson, op. cit.: 40

36 Fiałkowski, Tomasz, (2001), 'Plama', Tygodnik Powszechny, nr 36, 9.09. 2001.

37 Wajrak, Adam, (2009) 'Wielka lekcja Rospudy', Gazeta Wyborcza, 8.05. 2009.

38 Wojciechowski, Michał, (2004), 'Dla kogo przyroda?', Rzeczpospolita, 5.07. 2004.

39 These figures represent three outlets analyzed until December 2006 - the nation-wide daily "Rzeczpospolita", regional (Podlaskie voivodship) "Kurier Poranny" and the local internet forum. "Gazeta Wybor-
} 
rhetoric of modernization and the narrative of "keeping up" with the EU. As Prime Minister Jarosław Kaczyński put it: "This Nature [Natura 2000 programme] has expanded so much that we can hardly build anything now. [...] We have to protect nature in a rational way" he added, claiming that Poland has "too many" protected areas. ${ }^{40}$

The Rospuda controversy was hanging in the air for a long time before the actual conflict started. In the 1990s journalists and scientists informed about the disturbing projects to build a motorway through the valley of Rospuda several times, but the issue was not considered a "national" problem. When in June 2006 it turned out that the river is definitely to be endangered by the motorway, larger initiatives were started to protect it. The initial environmentalist network that can be discerned early in this phase was a rather small, diverse group consisting of Polish organizations and Polish branches of international activist associations. They all called for a civic protest against the motorway and sided with the newspaper Gazeta Wyborcza. Their potential power lay in the ability to provide alternative reports and expertise (dominating the "epistemic community"), as well as the claims to legitimacy based on certain morally derived values rather than political "ideologies". But before the end of 2007, the NGOs could hardly enter the decision-making process. Their views were ignored by the local authorities in Augustów and by the government. Their standpoint was denied any reasonability, and their "anarchic" demands were dismissed as "eco-terrorism".41 At this stage, the government's practices of denial were not followed by any concrete arguments, apart from the calling up of the value of development and the idea of modernization. PM Kaczyński said that "giving in to their [environmentalists'] demands can block the construction of highways and the use of EU money in Poland" and emphasized, that while he is in favor of "the environment", development has to be given priority. ${ }^{42}$ Whereas the environmentalists were already trying to redefine Rospuda as a "natural treasure", the government avoided any discussions of the river itself, concentrating on the "long belated infrastructural improvement" and the legal aspect of the project, thus marginalizing the competing frame.

When the media campaign launched by Gazeta Wyborcza gained momentum, new actors began to side with the environmentalists. The activists alone would not be able to enter the negotiations, especially in the situation when the construction works had already started. At this point already, the European Commission began contacting the Polish authorities and demanded "explanation". Without the strong media support the NGOs group could not gain any significant attention. As a major nation-wide daily, $\mathrm{Ga}$ zeta Wyborcza was able to create the space for debate almost instantly. However, only in early 2007, when the controversy was widely discussed in all Polish media, did the conflict reach its second phase - the authorities could no longer ignore the issue, and had to defend their framing of the problem.

\footnotetext{
cza" is excluded, because at that point the paper was already launching a wider campaign in support of the environmentalists.

40 Wajrak, Adam, (2006), 'Premier: Mamy za dużo chronionej przyrody', Gazeta Wyborcza, 7.08.2006.

41 The Prime Minister himself suggested that many environmentalists are only interested in (possibly foreign) "grants" and are not "people of good will", See: "Premier o sporze wokół Rospudy", Onet.pl, 16.02.2007.

42 Ibidem.
} 


\section{Phase II: Framing Struggle - The Conflict Escalates}

Already in the summer 2006 Gazeta Wyborcza, called for civic protests against the motorway. The daily gathered 160000 signatures under an appeal entitled "Saving Rospuda Valley", which was sent to the President Lech Kaczyński. The document suggested that the Rospuda river valley "belongs not only to the Polish but to the European heritage". ${ }^{43}$ The definition of Rospuda as a "unique natural treasure of European importance" which brings onto Poland the moral duty of "preserving it for the future generations in an untouched state" was a key element of the way this issue was framed by the environmentalists. In their view, the valley was priceless, and it was not possible to construct any motorway through that area. Thus the environmentalists challenged not only the "issue implications", but the frame itself. The advocates of the motorway framed the issue in terms of 1) development and 2) risk for the local population. They were presenting the whole "row" as a "media manipulation" over "a swamp, the protection of which brings 150,000 trucks to the town each month, taking the lives of local people and their children, making them suffer from lung diseases, exposing the town to noise, smog, and cracking ceilings".

The environmentalist side needed to achieve three things. Firstly, to attract attention and eventually gains support of a large part of the society. Secondly, to make the authorities engage in any sort of dialogue. Lastly, to make them engage in the dialogue on favorable terms - that is, framed as a question of environmental preservation of damage. The "greens" organized a "green ribbon" campaign to attract further attention and create a visual symbol of the controversy. At the same time, the issue was presented as a case of "bad governance" and "Europe-wide shame". The campaign was soon to be described as the largest societal action in the country: "Poland has not yet seen such an enormous civic campaign for the sake of environmental protection, evoking European values." 44 The developmental side lost its monopoly in the public sphere, but it still had the last say on policies.

Despite the media campaign, environment minister Jan Szyszko refused to change the route of the motorway, and the government was still using the rhetoric of modernization. Via Baltica was depicted as a key infrastructural investment, and the people of Augustów as victims of any delay in construction works (which could result from a change in the project). Since the issue was already publicized, but the authorities still refused to negotiate with the environmentalists, the latter started taking desperate measures in early 2007, when the construction works in the valley were just about to start.45

Denial and the strategy of ignoring societal voices of dissent reached its peak in February 2007, and the activists had no choice but to resolve to "non-rhetorical" action. When bulldozers were ready to enter the site on St. Valentine's Day, Greenpeace and other groups organized a camp ("The Green Town") on the route of the works, and numerous activists occupied the site. The camp was effectively blocking the construction works, in an attempt to delay them until 1. March, when strict bird-protection period would start, not allowing for any works on site.

Shortly before that, the ombudsman Janusz Kochanowski supported the protestors' claim that the decision in favor of the investment was breaking the law, and later also that it was against the Constitution. This was the first important "crack" in the pre-

\footnotetext{
43 The letter can be found at: http://www.kropla.sepzn.vel.pl/index.php?name=News\&file=article\&sid $=115 \&$ theme=Printer $(12.06 .2008)$.

44 Quoted after the website of SISKOM - Society for the Integration of Capital's Communication: http://siskom.waw.pl/siskom-dzialania-rospuda.htm (13.06.2008).

45 The regional governmental administration confirmed the route through Rospuda on 9. February.
} 
viously monolithic stance of the PiS government. It also created another aspect of the controversy, which was now not only about environment vs. development, but also the rule of law, human rights and participatory governance. As such, it became an issue that was impossible to be ignored any longer, and the government was forced to engage in dialogue. What is more, in December 2006 the European Commission and the DG Stavros Dimas accused Poland of breaking the Community law by planning motorway investments through the areas protected under the Natura 2000 program. The struggle around the issue of Rospuda literally conquered the Polish media in the months when the construction was supposed to take place. Between February and May 2007 the two major dailies alone published 195 pieces on Rospuda.

At this point, the authorities were forced to engage in an informed dialogue, at least with the European institutions. With that came the acceptance of the "environmental" frame of the Rospuda issue. Minister Szyszko denied any "value" of the valley, stating that "Rospuda is a human creation and nothing will happen, when the motorway will cut across it". ${ }^{46}$ Such statements were constantly questioned by the media, especially Gazeta Wyborcza, finally able to comprehensively argue with the officials. When the issue was framed as a tradeoff between "preserving pure and untouched nature" and "development above all", it was possible to measure the degree of public support. In a survey conducted at the peak of the conflict, $41 \%$ of Poles declared that "preserving nature is more important than modernization", while $24 \%$ opted for development (industrialization, modernization). $62 \%$ of respondents were against the motorway cutting through Rospuda, and 19\% were in favor of that project. ${ }^{47}$

In Podlasie, the region where Augustów lays, the figures were almost reversed, with 52\% supporting the motorway and there were still many who favored the project with possible compensations for the environment. The activities and strategies of the motorway supporters were quite similar (in fact, emulated those of environmentalists) and had a parallel timeframe. The local authorities started an "orange ribbon" campaign as a direct reply to the "green ribbons", and there was an website established to support the motorway. The town of Augustów was backed by its partner city in south-western Poland, Szklarska Poręba. Its inhabitants gathered signatures for a counter-appeal to the President, but as their action did not have a nationwide character, they managed to collect only a couple of thousand.

Despite the failure of their ribbon campaign, the supporters of the motorway still had the government on their side, along with the General Directorate for National Roads and Motorways, and the company that won the tender to build the motorway. They also gained attention in the media and were supported by Fakt, which is the only Polish newspaper with circulation and readership higher than Gazeta Wyborcza. The tabloid portrayed the eco-activists as "stupefied with the smell of rare flowers" unrealistic and irrational people "who are never content" and always prioritize "birdies, frogs and flowers" over the life and well-being of local people. ${ }^{48}$ Transnationally, the developmental side was bolstered by the Lithuanian government, since much of that country's import and export passes through Augustów.

It is important to note that the environmentalists began framing the Rospuda case in "transnational" terms early on. While the "transnational" dimension of the motorway was purely material, the vision of a "treasure of European heritage" that was

\footnotetext{
${ }^{46}$ Gazeta Wyborcza, 'List Otwarty w Obronie Rospudy' 11.02.06.

47 CBOS, (2007), Droga przez Dolinę Rospudy. Postawy wobec modernizacji i środowiska naturalnego, Warszawa: CBOS, Marzec 2007.

${ }^{48}$ Fakt ,'Kwiatek ważniejszy niż ludzkie życie“, 26.03.09.
} 
about to be destroyed seemed very appalling. Foreign newspapers picked up the "green" interpretation of the conflict and thus added to the general pressure on Polish authorities. German Die Welt published many articles regarding the Rospuda describing it as "a valley belonging to primeval forests, which is an asylum for eagles, lynxes, wolves" and other rare species; 49 and "the picturesque valley with protected moors".50 The paper reported on the "Green Town" where "around 70 foreign activists, among them many Germans" showed up. ${ }^{51}$ A similar attitude was represented by the Norwegian and Swedish media, which attributed to the area the uniqueness in European and global terms. ${ }^{52}$ According to The Guardian Rospuda is "the magical land that time forgot' and 'a valley that harbors Europe's rarest wildlife". 53

Polish environmental scientists, who in February voiced their solidarity with the "Green Town" and the whole campaign, called their Western colleagues for help, establishing an ad hoc transnational "epistemic community". They became a source of many authoritative (not only scientific, but also - foreign) statements. According to German and Dutch scholars, Rospuda is the best conserved moor west from the Ural mountains which implies that protecting it is not a local, but a serious European task. Academics also helped in shaming the General Directorate when they pointed out numerous mistakes in all policy-reports relating to motorway construction, e.g. inventing non-existent species of birds. With scientists came politicians: a Spanish member of the European Parliament offered tying himself to a tree to save the Rospuda valley. DG Dimas issued numerous statements that the Polish government is behaving inappropriately in Rospuda case.

The spreading political contestation and the controversy over Rospuda was effectively grafted onto some well established traditions and symbols of Polish "ideational landscape". One such grafting strategy, which was also at the heart of the Polish environmental movement in the $1980 \mathrm{~s}^{54}$ was to link preservationist arguments with the Christian conceptions of nature and the teachings of John Paul II. The supporters of the motorway on the other hand sided with the more conservative factions of the Catholic Church and attempted to reframe the issue as "Catholic values of life" vs. "civilization of death" (personified by the leftwing activists). However, the power of the Pope as a unifying symbol was greater and by definition more inclusive, and helped the environmentalists to keep their "ecological" frame and the idea of "protecting pristine nature" in place.

In practices that can be referred to as "politics of meaning", the "greens" were able to take over symbolic strongholds that affirmed their perspective and allowed their values to dominate in the debate. When the "Green Town" was set up, clear parallels were made to anti-communist dissent, and Rospuda was labeled "the new Solidarity". This was additionally strengthened by the presence of former Solidarity activists in the camp. In this "symbolic warfare" everything from high- to pop-culture became a contested issue, and the "pro-ecological" message of everything, from Romanticist Polish poetry to popular Czechoslovak cartoons was claimed. After the large media campaign came the involvement of "higher" forms of culture. Actors and artists issued an open letter to Szyszko, calling for the preservation of the Valley.

\footnotetext{
${ }^{49}$ Die Welt, ,Kaczyński gibt im Streit um Autobahn nach`31.07.07

50 Die Welt; ,Kaczyński gegen die Feinde Polens‘ 18.05.07

51 Die Welt, ,Polens Umweltschützer gehen auf die Bäume‘ 23.02.07

52 For a Norwegian example see: http://www.birdlife.no/internasjonalt/nyheter/?id=213 and for a Swedish example see: http://bulletinen.org/Bulletinen/web-content/Miljo/Rospuda2TP.html

53 The Guardian, 'Battle to Save the Magical Land that Time Forgot', 23.09.07

${ }^{54}$ Compare: Szulecki, K. op. cit.
} 
Visits of EU directorate were used to hold ecological gatherings and protests. "Moor's day" was organized in Poland in February 2007. While numerous people took to the streets in major cities (Krakow, Poznan, Gdansk and Warsaw) to support the environmentalists, demonstration against the eco-activists was held in Augustów. Throughout this phase of the conflict, the media on all levels were flooded with information and opinions on the Rospuda case. The advocates of the motorway were in a dominant position, and one third of the articles (in papers apart from Gazeta) argued from the perspective of "basic protection", another third part postulated "conservation", while 32\% of texts presented the hard-line environmental preservation point of view (see: Figure 2).

When the EU officials started to monitor the process and threaten Poland with "severe consequences", the Polish government responded with a bargaining tactic, based on the norm of environmental conservation rather than the advocated preservation. Szyszko and the transportation minister Polaczek were mentioning that many square kilometers of trees will be planted to compensate for the environmental losses in the Valley. This was meant as a tactical concession to tone-down the dispute, acknowledging the environmental framing, but pointing to different policy implications than those argued by green activists. This situation brings us to the next "step" postulated in the model, as both the "environmental" frame, and the advocated norm of environmental preservation have by this point (late spring 2007) achieved some relative superiority in the debate. Through a vast mobilization and an effective media campaign, reinforced with "difficult questions" from the representatives of European institutions, the government was rhetorically trapped and, with time, started to accept more and more implicit assumptions of the environmental discourse - and "talking the talk".

\section{Phase III: Relative Superiority - From "Cheap Talk" to "Entrapment"}

Apart from the symbolic "ribbon campaigns" and signatures collection, both sides started "blaming and shaming" actions against the rivals. Among the pointless insulting and offending there were some smart "traps" used by the environmentalist side. These concentrated on the President, and pressed him and his wife to side with the Rospuda supporters. Polish NGOs and Gazeta Wyborcza forced the President's spokeswoman to comment on the conflict. As she replied automatically that the environment "has always been important for President Kaczyński",55 the statement became a crucial instrument to pressure the head of state. It was used to portray the President as closer to the environmentalists. Further, careful statements made by the presidential couple were later used to label them as Rospuda's defenders. During an interview for Gazeta, the First Lady was asked if she wears a green ribbon. She replied that she would, but does not have one. When she was presented with a ribbon by the journalist, she had no choice but to put it on, and thus a picture of the President's wife siding with Greenpeace was spread by the media. ${ }^{56}$ The presidential couple was contrasted with the PM Kaczyński, who was strongly shamed for being the "worse" of the Kaczyński twins. As one of the journalists noted: "The premier says we have to modernize quickly and cheaply. But the civilized world has stopped modernizing like that long ago. You cannot rebuild damaged environment, once you get richer, and the costs of those damages are many times higher than the gains from quick and cheap development". 57

\footnotetext{
55 Gazeta Wyborcza ,'Ratujemy Rospudę: Mamy juz 50 tys. podpisów', 19.07.06.

${ }^{56}$ Gazeta Wyborcza, 'Maria Kaczyńska: Rospuda jest piękna, nie bądźmy barbarzyńcami', 22.02.07.

${ }^{57}$ Gazeta Wyborcza, 'Jarosław Kaczyński: Na Podlasiu tylko PiS’ 23.04.07.
} 
While such "symbolic" cases of what could be called situational entrapment helped to strengthen the position of the environmental side in the struggle, they were only later followed (once the ecological frame became clearly dominant) by instances of real, discursive entrapment, in which a party has no choice but to formulate its arguments within the boundaries set by the opposition and accept some of its assumptions - a visible sign of rhetorical coercion. The President indeed started to diverge from his brother's party standpoint, and explicitly "disapproved" of the construction works at Rospuda in late February, putting the PM in a very difficult position. From then on, the government's standpoint began to show even more "cracks" - PiS spokesman declared that "the Prime Minister is more and more open to the arguments of the environmentalists and the perspective of the EC". ${ }^{58}$ What is important, there was no such mechanism in the opposite direction. There was no successful blaming strategy on behalf of the motorway supporters. No important actor was persuaded from the "green" to the development side. The public sphere of debate was already dominated by the environmental framing and it was important for every participant to relate to their arguments.

But Minister Szyszko was far from being convinced by the ecologists. He kept his permission for a trestle bridge above the Rospuda Valley, close to the most valuable and protected sites, cynically signing the decision precisely on "Moor Day". The second "peak" of the conflict came in the summer of 2007 when the "Green Town" was established again with the end of the bird protection period.

The environmental side, having mobilized thousands in support of their cause already, launched a series of new campaigns (e.g. trees "adoption, passports of the "Republic of Rospuda"). Environmental activists lead by Gazeta's journalist Adam Wajrak begun to buy small pieces of land on the planned route through the valley, and refused to sell them to the state. More celebrities and prominent cultural figures expressed their support for the "greens" - "Requiem for Rospuda" was part of the season's popular theatrical play, and the "Przystanek Woodstock" rock festival, gathering over 100000 young people, was almost entirely dedicated to the issue.

By late spring 2007 the EC started blaming Poland for breaking Article 10 of the EU's Treaty as well as the Habitat Directive. A reasoned opinion was issued, followed by a case brought before the ECJ. Additionally, the Commission issued a petition to the Court for an immediate suspension of construction works. ECJ started the hearings in April did not have to propose any sanctions, since the Polish government suddenly changed its tone. ${ }^{9}$

The electoral struggle which reached its peak in the summer blurs the situation to some extent, as the opposition, by definition, was ready to question the validity of judgment of the government about to leave office. And yet, by looking at the way the four norms/values were represented in the media, we notice a considerable change in public discourse. The relative superiority of the "environmental preservation" norm becomes visible - being expressed in 59\% of the pieces published from May until December 2007 (Figure 2).

\footnotetext{
58 Gazeta Wyborcza, 'Kto zatrzyma budowe przez Dolinę Rospudy?' 23.02.07.

59 The ECJ also refused to use the faster procedure in the Rospuda case, which meant that the verdict could take up to two years, and suggested, that the ECJ cedes the whole responsibility onto Polish judiciary.
} 


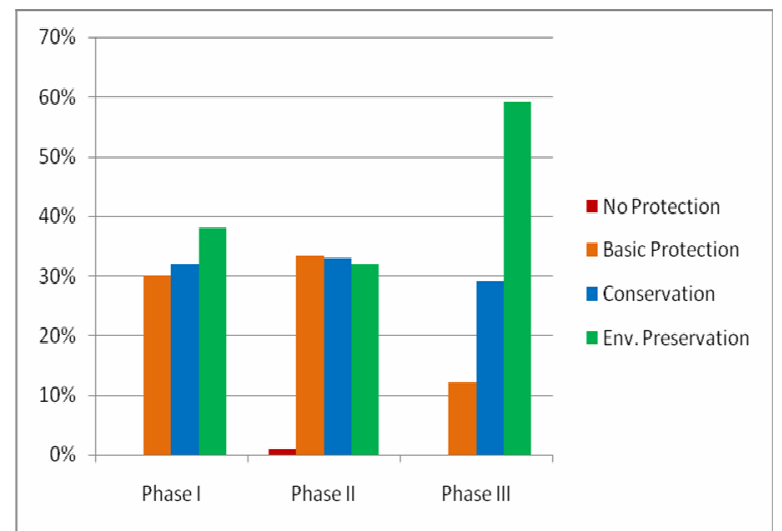

Figure 2 - Representation of Values/Norms in the media

Despite the observable dominance of the environmental perspective and preservation norms in the nationwide discourse, the regional ambiguity and local dissatisfaction with the campaign against the motorway had to be dealt with. The ecological frame had little resonance with the way the issue was perceived by the people of Augustów. To bridge this cleavage, the "greens" defined the Rospuda controversy as an instance of "bad governance", which led to a situation where all the stakeholders are unhappy with the way problems are resolved. This definition dominated the pre-electoral period (46\% of all articles about Rospuda referred to governance malpractices at the peak of the conflict, 30\% right before the elections), and became a common platform of constructive critique for all the media (Fakt, Gazeta, Rzeczpospolita), as well as for both sides of the conflict. We argue that this realization is constitutive for the change in governance patterns that could be discerned in Poland as a result of the controversy.

In April 2007 the Regional Administrative Court in Białystok revoked the "environmental decision", necessary to conduct construction works in Rospuda. In the summer, the PM Kaczyński ordered to stop the works until the ECJ would voice its judgment. Later that summer, the public was shocked by the newspapers announcing that the General Directorate has concealed the true results of an advisory report it had commissioned, where an independent consultancy rated the motorway through the Rospuda Valley as the worst possible solution. ${ }^{60}$ This moment coincided with parliamentary elections, where the factor of international "shame", in which the Rospuda case played an important part, brought about a serious change on the political scene. Kaczyński's PIS lost the elections and a coalition government of the liberal Civic Platform (PO) and the agrarian Polish People's Party (PSL) was established. In his expose, the new PM Tusk discussed claimed that "Natura 2000 [...] is not bound to cause conflicts between the tasks of environmental protection and the economic development of the country". Despite his clearly liberal and utilitarian views, he emphasized "respect for nature" and "dialogue" as the necessary elements of Poland's sustainable development, at the same time referring to the "green" mobilization of the Rospuda campaign and "bad governance". ${ }^{61}$ In early December 2007, the new environment minister Maciej Nowicki commented on the conflict: "I have just recently read the opinion by the National Council for Nature Protection, and I realized how valuable this area is. It's the only soligenic peat-land in Poland,

60 Dziennik, 'Obwodnica przez Rospudę to najgorsza opcja' 2.08.07.

${ }^{61}$ The full text of the expose is available at: http://www.rp.pl/artykul/71439.html (3.09.09). 
which is a post-glacial relict." 62 Leaving the question of true intentions aside, it seems that this was the legitimate thing to say at that point.

\section{Phase IV: Stable Position}

From December 2007 onwards the debate radically changed. The authorities gave up their position of power and started an "egalitarian" debate with the "civil society representatives", in an effort to, as the PM Tusk put it, "put the debate back on its feet, as it was standing on its head until now". 63 They established a Round Table which, especially in the post-communist Polish context, symbolizes the equality among actors is search for best solutions. ${ }^{64}$ According to the Ministry of Infrastructure spokesman, the Table was "an independent decision of the government, not enforced by any societal pressures."65 This is a debatable statement, but the decision did come from the new minister of environment. ${ }^{66}$ The Table met for the first time in January and agreed that only three variants of the motorway would be taken into account: 67 The controversial by-pass of $\mathrm{Au}-$ gustów through the Rospuda, with additional versions (tunnel, suspension bridge); the environmentalists' proposal passing near the village of Chodorki; and a new governmental proposal through the village of Raczki. The General Directorate representative spoke in favor of the first variant, but noted that although "it is a proposal we worked on for 15 years, it has all the documentation, it does not mean that we are digging trenches and not willing to let go. We are here to find a compromise." Even though the Table was meeting on an irregular basis and lost much time waiting for the results of additional expert analyses, as well as a large scale round of societal consultations on grass-root level, it soon became clear, that only one of the alternative projects has a chance of being chosen.

In the meantime, several similar potential conflicts between modernization and the environment emerged, but they were either automatically resolved in favor of the environment, or conciliatory policy networks were called up, involving environmental activist groups, local populations, the authorities and the private sector. A good example is the conflict between the modernization of an airport near Świdnik in Central-Eastern Poland and the protection of endangered gofers who have their habitats on nearby fields. "The Rospuda case turned out to be a revolution in the fashion in which decisions are made. In Świdnik dialogue was established from the start, reconciling the locals and the environmentalists without unnecessary costs and conflicts." 68 This shift in governance procedures lead to a quick resolution and thus both the planned renovation of the airport and saving the gofers' habitats. A less publicized case is that of the S16 motorway (Via Baltica as well) near Białystok, which was supposed to cut through the protected areas of Puszcza Knyszyńska. The construction permit for that section of the motorway was cancelled by the regional administrative court on the same day as the verdict over Rospuda was made, and clearly on the same basis. ${ }^{69}$ More importantly, the government

62 Gazeta Wyborcza, 'Okrągły stół dla Rospudy' 7.12.07.

${ }^{63}$ Quoted in: Wirtualna Polska 'Tusk zapowiada ochronę interesów narodowych w Unii' 4.12.07.

64 The participants of the Table were: the General Directorate, regional and local authorities, NGO representatives and invited experts. Among the observers were representatives of several ministries and parliamentary committees, as well as the European Commission.

65 Piort Pastuszak, Biuro Informacji i Promocji, Ministerstwo Infrastruktury. An e-mail interview by the authors, 12.06.2008.

66 The same suggestion is made by a representative of the local authorities, who says that the decision was made "solely by the Minister". Urząd Gminy Augustów, e-mail interview by the authors, 6.06.2008.

${ }^{67}$ Later the Table gathered only twice: on the 19.01 and 4.02.

${ }^{68}$ Gazeta Wyborcza 'Jak dzięki Rospudzie powstało lotnisko w Świdniku, a susły nie zginą' 19.07.07.

${ }^{69}$ PAP 'WSA uchylił decyzję ministra środowiska ws. obwodnicy Wasilkowa' 08.01.08 
announced that it is finally going to prepare the long overdue list of Natura 2000 protected areas through consultations with NGO experts and activists. "This is a breakthrough" said Przemysław Chylarecki of the Polish Bird Protection Society. ${ }^{70}$

While the government sustained its point of view on the conflict and emphasized the need for a societal debate and dialogue at the Round Table, the lower level administration made an attempt to continue the motorway through Rospuda as a fait accompli. An environmentalist produced photographic evidence of continued construction works just 400 meters from the border of the Natura 2000 protected area. A bridge over a local road would be completely useless and a significant waste of money, should the route of the motorway be changed. ${ }^{71}$ This was meant as an argument for the rapid continuation of the existing variant of the road. The environmentalist participants of the Round Table were furious at the news, and suggested, that the General Directorate's local branch is "breaking the consensus it helped negotiate" and that "it is unclear if the road builders are governed by the government or vice versa." 72 The Ministry of the Environment demanded explanations from the local authorities and the Directorate, which claimed that while the courts have obliged them to stop any works within the protected Natura 2000 areas, construction outside these zones was still legal. After the governmental intervention these too were put on hold. This case of a "non-discursive" way to influence the debate can be seen as the exact opposite of the way environmentalists acted at the early stage of the controversy, especially when the "Green Town" was established. It therefore shows the way empowerment of the competing positions was reversed, and the supporters of the motorway were forced to use "guerilla" tactics to counter the dominant norm.

It took the courts longer to officially question the legality of the Via Baltica through the Rospuda Valley. While the regional prosecutor acted immediately after the issue was taken up by the Ombudsman, and the regional administrative court suspended the construction permit already in April 2007, the higher instances were slower. The High Administrative Court made its final verdict on September 16. 2008, dismissing the General Directorate's appeal, and thus effectively stopping the construction works. ${ }^{73}$ In December the last remaining permit was revoked by the administrative court in Warsaw, and the General Directorate was forced to renounce the contract with the construction company. A report commissioned by the Round Table was made public in February 2009, suggesting that the motorway cannot in any form run through the Rospuda marshes without breaking the EU law and damaging the natural site. ${ }^{74}$ Finally, after years of struggling, on March 24. the Interior Minister and deputy-PM Grzegorz Schetyna arrived in Augustów to announce (after consulting the local authorities of the communities through which the road would pass), that the motorway would be built through Raczki (thus D-touring the protected areas) "or not built at all."75 This decision was followed by another series of consultations with the local councils conducted by the head of the Podlaskie voivodship, who explains: "I want to build a partnership for the construction of this road, therefore I decided to have such meetings, even though they are not my duty."76 In

\footnotetext{
70 Gazeta Wyborcza, 'Rząd dogadał się z ekologami, czyli zielone światło dla dróg' 25.04.08.

${ }^{71}$ Expenditures rose from PLN 80mln in January to PLN $180 \mathrm{mln}$ in July 2008, even though the works were officially on hold.

72 Gazeta Wyborcza, 'Budują, choć nie powinni' 12.07.08.

73 Wyrok Naczelnego Sądu Administracyjnego z dnia 16.09.08, Sygn. akt. II OSK 821/08.

${ }^{74}$ Medek, Jakub, (2009), 'Obwodnica przez Rospudę, ale nie przez bagna' Gazeta Wyborcza 22.02.09.

75 Gazeta Wyborcza, 'Rząd decyduje o obwodnicy' 24.03.09.

${ }^{76}$ Gazeta Wyborcza, 'Wojewoda porozmawia z samorządowcami o Rospudzie' 30.03.09.
} 
mid-April 2009, the EC withdrew the Rospuda case from the ECJ,77 thus putting an end to this conflict.

\section{Conclusion}

When can the process of norm enforcement, bringing with it a discursive and policy related change, be expected to occur? We argue that a sufficient level of domestic publicity (for the controversy to become an issue that the authorities cannot ignore) and the involvement of European institutions and actors were key catalysts in the process. However, the role of the EU can be ambiguous. It is possible to imagine scenarios where the activists are advocating a norm which is not accepted by the EU (e.g. exclusive nationalism) and external actors side with the government. More important and clearer is the role of the EU as a stabilizer of the norm (if it is shared by the EU itself) once it reaches relative superiority over competing norms.

What would be the result of the conflict if the environmental activists were to act alone? It is difficult to conduct such counterfactual analyses, but a brief comparison with a similar case in Ireland can perhaps give a hint as to the possible outcome. In 2006 the project was confirmed to build a motorway through the legendary Tara Valley, perhaps the most important site for Irish historical and cultural heritage. ${ }^{78}$ The advocacy networks in both cases developed in a similar manner, emphasizing heritage and "intangible values" against material concerns and "cheap modernization". However, the Irish activists were not able (or willing) to frame the issue in wider, European terms. The Tara controversy remained a domestic problem, and effectively ended when a number of activists (like their Polish counterparts) attempted to use non-violent civic disobedience and block the construction works. They were arrested, and the works continued. ${ }^{79}$ This shows the crucial role of framing in both domestic and transnational mobilization a factor that can bring either failure or eventual success.

The EU supplemented rhetorical coercion with material coercion, but it was not the Commission that framed the issue "on the ground" and mobilized societal groups. European involvement was in this case necessary, but is not sufficient for the conflict to play out either way. The analysis shows how important (and complex) the domestic level is, and how fluctuant rhetorical battles can become. It is crucial to conduct meticulous inductive research on domestic discourses - without this important definitions, frames or elements of "ideational landscapes" with which they resonate can be overlooked. Domestic agency is also the main element of political contestation, one that can be enforced from the outside, but can never be substituted with mere transnational action.

As a result of the controversy Rospuda itself became a symbol or a "commonplace" in Polish political discourse. Already in 2007 the idea of "Rospuda" as an instance of a larger phenomenon has appeared in 38 articles. ${ }^{80}$ When environmentalists and "ordinary citizens" were defending Warsaw's largest park from partition and urbanization,

\footnotetext{
77 European Commission 'Koniec sporu o Rospude', 15.04.09. At: http://ec.europa.eu/polska/news/ 090414_rospuda_final_pl.htm (28.04.09).

78 Battersby, Eileen, (2008), 'Is nothing sacred?', The Irish Times. At: http://www.ireland.com /newspaper/newsfeatures/2007/0526/1179498835274.html. (30-01-08).

79 Ziemińska, Julia (2008), 'Heart of Ireland, Lungs of Poland A Comparative Study of the Issue Networks Established to Protect the Tara and Rospuda Valleys', Working Paper, unpublished.

${ }^{80}$ From April until December 2007 in all four outlets analyzed.
} 
they named their initiative "Our Rospuda". This shows how an actual issue can become a firm element of the "ideational landscape" in a matter of months, and thus be used in future rhetorical coercion.

Framing struggle is perhaps the "hottest" phase of the conflict, and framing is definitely at the heart of the model. As we have shown, a resonant frame can unite actors with very different identities over a single value/norm (eg. greens, the Church, neoliberals, leftists, and anarchist at the "Przystanek Woodstock" festival). Thus identities become analytically irrelevant in the analysis of such conflicts - what matters is rhetoric and declared attitudes towards policies. On the other hand, frames cannot explain everything. As heuristics, they organize indirect experiences. Figures from Augustów and the neighboring areas show that people with a firsthand experience of the problem, whom the issue touches "directly", will not enter any frame contest. The unifying notion of "bad governance" was present in their definitions of the issue all along, and it was part of a larger, critical strand of Polish political discourse. The largest shift in perspective was observed in the regional (not local and not national) media - close enough for the issue to matter, but detached enough to abstract from it. On the national level it was much more mobilization and rhetorical coercion than actual "conversion" that mattered. In this sense, we suggest to look at such normative struggles and societal campaigns of political contestation rather as something resembling an electoral campaign than "learning", "socialization" or "norms diffusion". 